Article

\title{
An Analysis of Public Complaints to Evaluate Ecosystem Services
}

\author{
Jae-hyuck Lee ${ }^{1}\left[\right.$ and HaeOk Choi ${ }^{2, *}$ \\ 1 Korea Environment Institute, 811 Building B, Sejong National Research Complex 370, Sicheng-daero, \\ Sejong 30147, Korea; jaehyuck@kei.re.kr \\ 2 Science and Technology Policy Institute, 508 Building B, Sejong National Research Complex 370, \\ Sicheng-daero, Sejong 30147, Korea \\ * Correspondence: hochoi@stepi.re.kr; Tel.: +82-44-287-2305
}

Received: 20 January 2020; Accepted: 20 February 2020; Published: 25 February 2020

\begin{abstract}
Reducing the demands placed on ecosystems can maximize the benefits they provide. Therefore, this study examines public complaints about the environment to analyze the pressure placed on the ecosystem spatially and temporally. Environment-related public complaints filed in the city of Namyangju were examined. The city sources its water from the Han River and is poised to implement a payment system for ecosystem services. Many complaints were filed regarding noise and oscillation, dust scattering, wildlife, air quality management, and water quality management. The complaints indicated that the public were inconvenienced by the regulation of services and service-support: scattered dust affected the downtown area all year, while noise and oscillation, as well as problems with air quality, were prevalent mainly during the summer. Measures should be adopted to address the peculiarities of each issue. This study suggests that areas in which wild boars are active should be separated from areas of human activity and that pollutants need to be prevented from reaching the waterfront. Measures should be developed to address the negative factors and maximize ecosystem benefits. Analyzing public complaints about the environment can lead to the establishment of local plans to maximize ecosystem services.
\end{abstract}

Keywords: pressures on the ecosystem; public complaints about the environment; Namyangju; reduction of ecosystem benefits

\section{Introduction}

Ecosystem services are benefits derived from ecosystems [1-6]. Ecosystem service assessment is related to monetary values, which suggests that there could be base earning incomes in conservation areas by sharing the profits of development. This approach could restrain the polarization and alleviate the wasting paradigm of competition between conservation and development. In this context, ecosystem services are used as a new concept of environmental planning. There have been many attempts to use ecosystem services for decision-making in environmental policy [7-9].

Most existing research has focused on analyzing and improving the functions of ecosystem services on the supplier side [10-13]. By assessing and mapping ecosystem services according to the whole and subdivisions (provisioning, regulation, supporting, and cultural services), environmental planning and spatial planning could increase the benefits of ecosystem services. However, consideration should be given to reduce the risk factors when increasing the benefits of ecosystems. Environmental problems should be addressed to optimize these benefits [14]. While the improvement of positive ecosystem services is needed, a reduction of negative ecosystem services is also important. Before maximizing ecosystem services, existing issues in the local ecosystem should be examined [15-18]. 
This study focuses on public complaints concerning ecosystem services. Payment systems for ecosystem services, which are policy measures designed to utilize them effectively, offer financial benefits to residents who are facing difficulties due to ecosystem preservation efforts [19-24]. Ecosystem services should reflect the characteristics of the local ecosystem as well as the nature of public complaints. An examination of public complaints will help local governments understand the issues surrounding ecosystem services. Although a few studies have considered environmental complaints, they did not analyze the contents of complaints; they simply assessed motives based on the main complaints on survey and contamination measurements [25-27]. However, this study examines local complaints in detail to better understand the relationship between ecosystem benefits and public engagement at the local level.

Public complaints represent community distress and are frequently examined in the field of marketing [28-31]. In marketing, complaints are used to suggest alternatives in a spatial context. In online shopping or hotel management, text mining is used to analyze complaints [32-35]. The spatial relationships between snow complaints and traffic crashes, as well as among sinkholes, dry-well complaints, and groundwater pumping have been analyzed [36-39].

It is necessary to analyze ecosystem complaints in order to understand spatial transitions in ecosystems [40-43]. This study investigates the negative factors of ecosystem benefits such as construction and pollution using a content analysis of public complaints about ecosystem services in a local area $[11,44,45]$. This study further examines the temporal and spatial characteristics of public environmental complaints in an effort to involve the local economy and lessen the negative factors of ecosystem benefits.

\section{Literature Review}

Ecosystem service assessment is the evaluation of benefits received from the natural environment. Many studies have performed various supply assessments of ecosystem services, such as an assessment of the supply of rice provisioning ecosystem services by yield data [46], the regulation of ecosystem services by ecological modeling [47], and cultural ecosystem services (urban green spaces) by a survey [48]. A time-series evaluation is meaningful for suggesting environmental policies to improve ecosystem services values by comparing the past status to that of the present. Such an evaluation is related to the development of ecosystem service mapping studies for environmental planning. In studies on ecosystem services assessment, demand as a social aspect and supply as a natural aspect are related $[49,50]$ and compared $[40,51]$.

The various ecosystem service mapping studies have led to the question of how to find a balance between suburban areas that have sufficient ecosystem service supplies and urban areas where numerous people need ecosystem services. Various ideas about spatial matching surpluses and the deficiency of ecosystem services have been suggested. In these studies, the spatial structure of ecosystem services demand has been analyzed based on population [40] and environmental modeling [52,53]. However, these approaches had the limitation that local ecological issues did not appear due to particular future scenarios regarding ecosystem services, and the matrices between ecosystem service indicators and land use. Therefore, the results of such research are detached from immediate, local policy and decision-making. To overcome this gap, cultural ecosystem services related to behaviors have been analyzed through interviews with local residents [28,54]. However, this approach is also unable to cover all the dimensions of ecosystem services.

The present study focuses on environmental civil complaints to understand the local issues in ecosystem service assessments. In many studies, complaints have been used to analyze the needs of users $[29,31,55,56]$. Complaints can indicate risk factors in terms of suppliers and help policymakers to determine the needs of users. This shows that analyzing environmental complaints is essential for policy-making and environmental planning based on ecosystem services. This study presents the demand for ecosystem services through an analysis of temporal and spatial patterns of environmental complaints and suggests environmental policies based on local issues. 


\section{Materials and Methods}

\subsection{Study Area}

Namyangju, which is located near Seoul, is the water supply source for the Korean capital of Seoul; 700,000 people live there. Urban development is restricted outside of certain areas in order to protect the quality of the water. Instead of expanded development, the city imposes a water usage charge on the citizens of Seoul, so that residential support projects can be implemented for those who live in development restricted areas. However, the number of people moving into Namyangju has been increasing by over 10,000 people per year, and residential development is growing rapidly. The interplay of restriction and development has prompted the city to introduce a water usage charge called the ecosystem services payment system. This is the context for this study (see Figure 1).

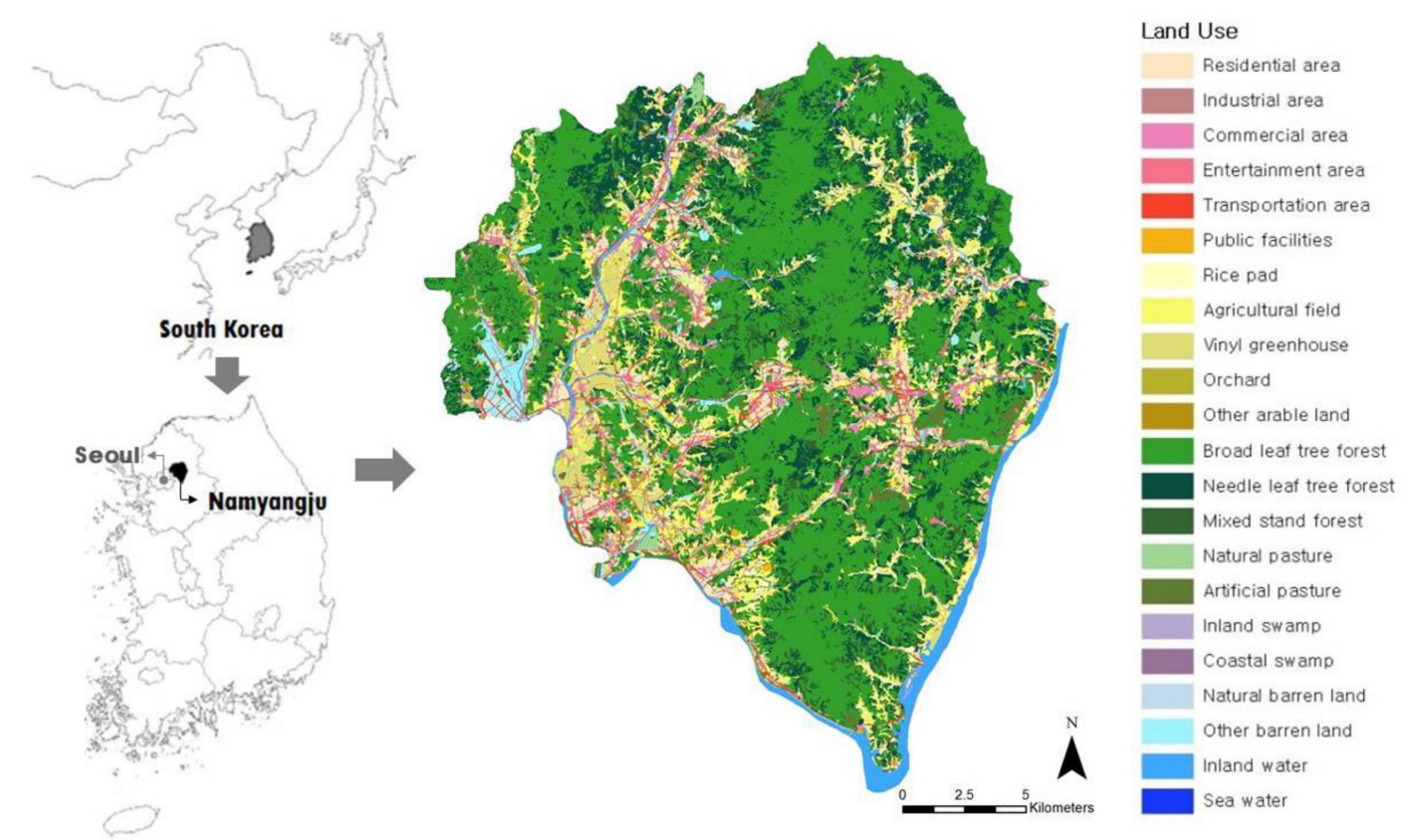

Figure 1. Study area.

\subsection{Method of Analysis}

This study examines public environmental complaints to investigate the factors that contribute to the reduction of ecosystem benefits. First, a content analysis of the environmental complaints received by the Namyangju government was conducted. To establish a framework for content analysis, this study used the existing categorization system in Namyangju for recording public environmental complaints (Table 1). For content analysis, complaints were classified according to four main (e.g., air, water, pollutant) and 30 subcategories (Namyangju suggested administration). These were then reclassified according to time (year and month) and place (administrative area). These steps were completed using Microsoft Excel. Environmental complaints from 2012 to 2016 were analyzed, with a total of 19,482 complaints received from 546 people. The number of complaints per person ranged from 1 to 1293 . This study focuses on the temporal and spatial patterns of complaints, with the assumption that a higher level of complaints indicates that more severe distress is being caused.

Second, a temporal analysis was conducted on the temporal characteristics of the categorized public complaints. Third, a spatial analysis was conducted by ArcGIS 10.3. It examined the types of public complaints that were filed and the prevalence of different types in various municipal areas of Namyangju over the course of 12 months (see Figure 2). Finally, this study identified the specific time 
and location at which the majority of public complaints were made and studied the contents of those complaints in an attempt to resolve the issues.

Table 1. Namyangju government's categorization system for environmental complaints.

\begin{tabular}{|c|c|c|}
\hline No. & Categories & Subcategories \\
\hline 1 & Air & $\begin{array}{l}\text { Air pollution measurement, air quality improvement, companies emitting air } \\
\text { pollutants, dust scattering, early scrapping of old vehicles, in-depth inspection } \\
\text { of vehicle emissions, low-emission diesel vehicle, natural gas bus support } \\
\text { project, noise and oscillation, subsidy for gas emission reduction device }\end{array}$ \\
\hline 2 & Water & $\begin{array}{l}\text { Companies dumping wastewater, special areas for water quality preservation, } \\
\text { waterfront zone, water quality improvement, water quality management, water } \\
\text { supply source protection zone }\end{array}$ \\
\hline 3 & Pollutant & $\begin{array}{l}\text { Toxic material management, total pollution load, total pollution load } \\
\text { management system }\end{array}$ \\
\hline 4 & Other Public Items & $\begin{array}{l}\text { Environmental grievance mediation with others, environmental improvement } \\
\text { charge, green growth, Green Start Network, natural environment protection, } \\
\text { private toilets available to the public, public toilets, soil management, licensing } \\
\text { of discharge facilities, resident support project, wildlife }\end{array}$ \\
\hline
\end{tabular}

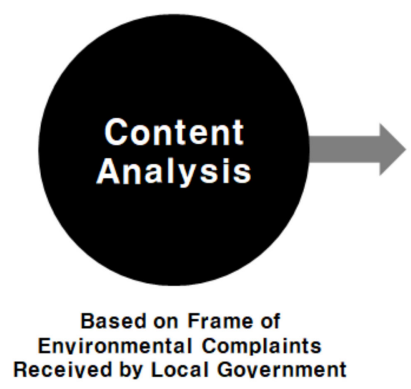

Environmental Complaints
Received by Local Government

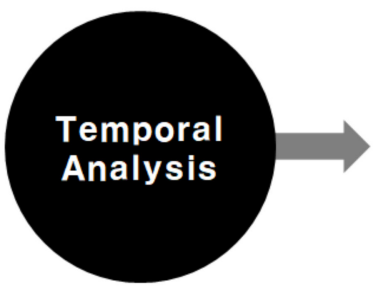

By Month and Year

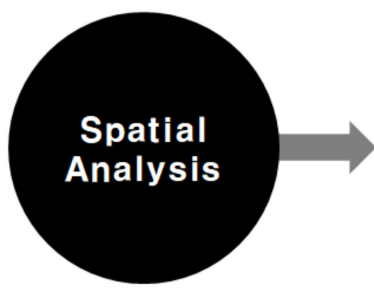

By Administrative District

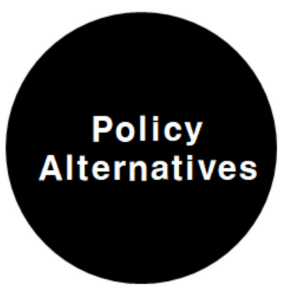

To Reduce the Risks of Ecosystem Benefits

Figure 2. Process of analysis.

\section{Results}

\subsection{Basic Statistical Analysis of the Public Environmental Complaints in Namyangju}

The analysis revealed that the majority of public complaints were related to noise and oscillation. These were followed in order by dust scattering, wildlife, air quality management, and water quality management. There was a strong demand for an enhancement of the regulation of ecosystem services in Namyangju. This study conducted an in-depth analysis of the top five categories of public complaints (i.e., noise and oscillation, dust scattering, wildlife, air quality management, and water quality management; Table 2).

Table 2. Basic statistics of public complaints in Namyangju (the darker the cell is, the more complaints).

\begin{tabular}{ccccccc}
\hline Year & $\mathbf{2 0 1 2}$ & $\mathbf{2 0 1 3}$ & $\mathbf{2 0 1 4}$ & $\mathbf{2 0 1 5}$ & $\mathbf{2 0 1 6}$ & Total \\
\hline Noise and oscillation & 1722 & 2197 & 2058 & 1909 & 2470 & 10,356 \\
Dust scattering & 628 & 701 & 597 & 650 & 805 & 3381 \\
Wildlife & 311 & 253 & 358 & 318 & 735 & 1975 \\
Air quality improvement & 145 & 175 & 423 & 208 & 266 & 1217 \\
Water quality management & 205 & 311 & 192 & 151 & 163 & 1022 \\
Public toilets & 74 & 80 & 77 & 98 & 173 & 502 \\
Companies dumping waste water & 64 & 58 & 76 & 53 & 79 & 330 \\
Companies emitting air pollutants & 81 & 39 & 41 & 7 & 21 & 189 \\
Environmental grievance mediation with others & 1 & 10 & 32 & 22 & 66 & 131 \\
Green growth & 10 & 19 & 15 & 14 & 9 & 67 \\
Air pollution measurement & 14 & 9 & 20 & 11 & 5 & 59 \\
\hline
\end{tabular}


Table 2. Cont.

\begin{tabular}{ccccccc}
\hline Year & $\mathbf{2 0 1 2}$ & $\mathbf{2 0 1 3}$ & $\mathbf{2 0 1 4}$ & $\mathbf{2 0 1 5}$ & $\mathbf{2 0 1 6}$ & Total \\
\hline Natural environment protection & 5 & 2 & 5 & 14 & 10 & 36 \\
Soil management & 7 & 13 & 10 & 3 & 2 & 35 \\
Natural gas bus support project & & & & 3 & 29 & 32 \\
In-depth inspection of vehicle emissions & 11 & 6 & 2 & 6 & 7 & 32 \\
Total pollution load & 1 & 2 & 6 & 1 & 6 & 16 \\
Water supply source protection zone & 2 & 3 & 3 & 2 & 5 & 15 \\
Toxic material management & & 4 & 4 & 1 & 3 & 12 \\
Environmental improvement charge & 6 & 2 & 2 & 1 & 1 & 12 \\
Private toilets available to the public & 3 & 1 & 2 & 2 & 3 & 11 \\
Water quality improvement & 2 & 1 & 3 & 2 & 1 & 9 \\
Low-emission diesel vehicle & 2 & 1 & & 1 & 3 & 7 \\
Waterfront zone & 1 & 1 & 3 & 1 & 1 & 7 \\
Resident support project & 1 & 3 & & & 3 & 7 \\
Early scrapping of old vehicles & & & 1 & 3 & 2 & 6 \\
Licensing of discharge facilities & & 1 & 4 & & & 5 \\
Total pollution load management system & & & 1 & 2 & 1 & 4 \\
Special areas for water quality preservation & & 1 & & 1 & 1 & 3 \\
Green Start Network & & 1 & 1 & & & 2 \\
Subsidy for gas emission reduction device & & & 1 & & 1 & 2 \\
$\quad$ Total & 3296 & 3894 & 3937 & 3484 & 4871 & 19,482 \\
\hline
\end{tabular}

\subsection{Analysis of Public Complaints by Monthly Distribution}

This study performed a spatial analysis on the characteristics of complaints from 1 January 2016, to 31 December 2016 (the year of the most recent data) for months in which the most public complaints were filed. A time-series analysis revealed that there were numerous public complaints about noise and oscillation, wildlife, air quality management, and water quality management during the summer months of June, July, and August. Complaints about dust scattering, however, were filed inconsistently throughout each year (Figure 3).

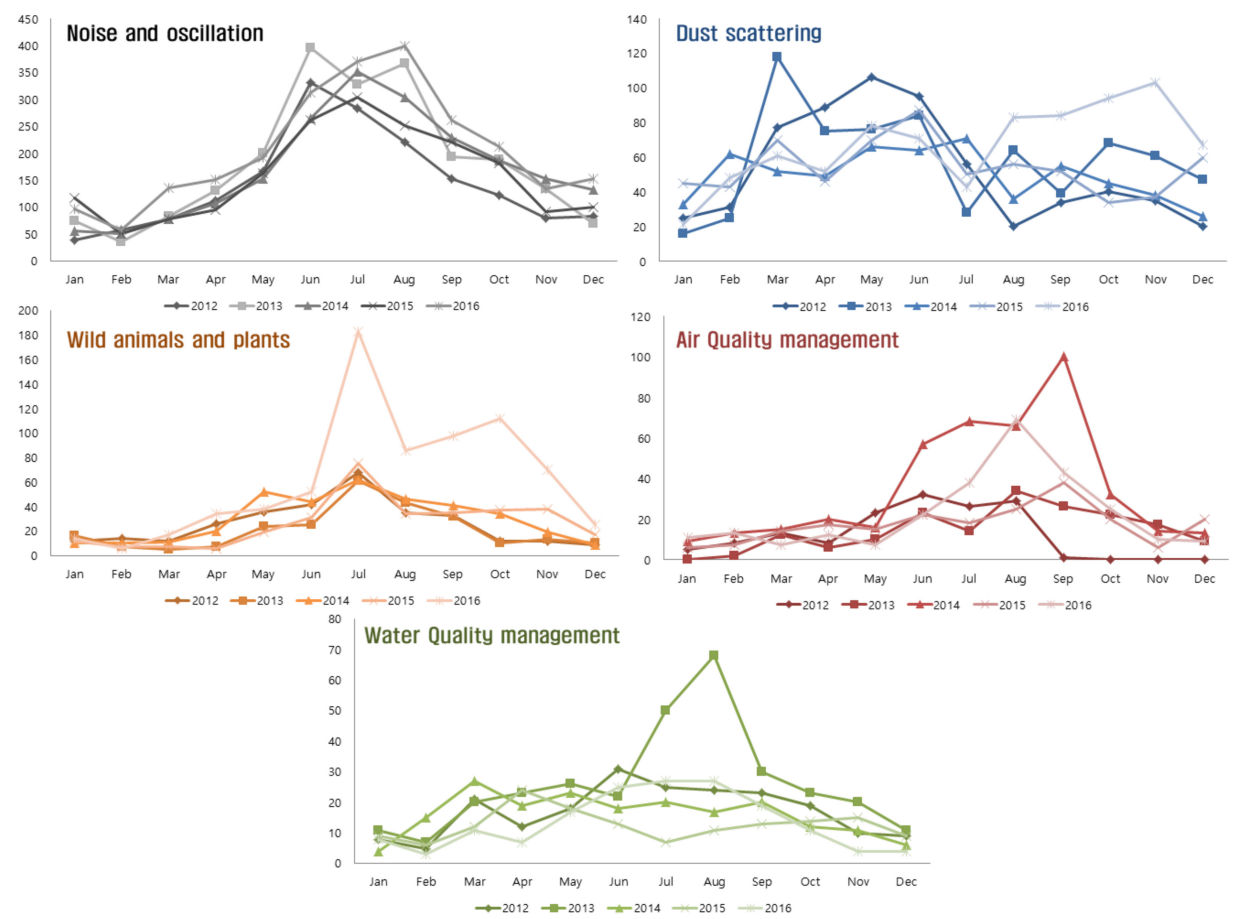

Figure 3. Monthly changes in public complaints per year. 


\subsection{Spatial Analysis}

A spatial analysis was conducted on the complaints about noise and oscillation, air quality management, and water quality management received in August 2016. This was the time period in which the greatest number of complaints were filed. Similarly, a spatial analysis was performed on complaints about wildlife made in July 2016 and complaints made about dust scattering in November of 2016 (these months had the highest level of complaints about the respective subcategory). The majority of public complaints about noise and oscillation, dust scattering, and air quality management were filed in Hwado-eup. Complaints about wildlife, however, were often reported in Byeolnae-myeon and Wabu-eup. A large number of complaints about water quality management were filed in Hopyeong-dong. After the spatial analysis was performed, Hwado-eup was specifically examined for public complaints about noise and oscillation, dust scattering, and air quality management, while Hopyeong-dong was examined for complaints about water quality management, and Sudong-myeon was examined for complaints about wildlife (see Figure 4).

According to a detailed analysis of complaints in Hwado-eup, dust scattering affected various construction sites in the downtown area. Public complaints about dust scattering included "At the mountain reclamation site, large construction vehicles are traveling in and out without their wheels being washed, leaving roads muddy. Please force them to assign people to wash the vehicle wheels and sprinkle some water over the roads. There have been many complaints, but they fix the problem only temporarily" and "At Nokchon-ri, the company is currently doing construction work. The vehicles are passing through the front yard of my house, and the yard is filled with dirt from the wheels of the concrete mixer trucks, and dust is scattering everywhere. I've asked the construction company to do something about it, but no action has been taken. Please make them wash my front yard when they are spraying water".

In addition, people in the central downtown area, who were already dealing with the issue of dust scattering, filed many complaints about noise and oscillation, and air quality management. Public complaints about noise and oscillation included "The apartment construction site in Nokchon-ri is making noise oscillation too much. I've been on leave from work for depression and insomnia, but I'm currently under a lot of stress due to the construction work. Please check the site and do something to fundamentally solve this problem" and "The construction site in Maseokwoo-ri is too loud during the early weekend mornings. Please check and find solutions to it." Complaints about air quality management included "It's about the construction site of the apartment in Nokchon-ri, Hwado-eup. Not just the noise, but also the vehicle exhaust from the site is making it difficult to do daily things. Please check and act to resolve the issue," and "The apartment, Nokchon-ri, Hwado-eup. Besides the noise, the air is gray with dirt. I work in the field of construction myself, so I can understand it to a certain level, but the dirt is excessive. Please, come and do something about it". These complaints suggest that a year-round measure should be implemented to control dust scattering in the entire downtown area, but measures to manage noise and vehicle exhaust should be implemented in specific areas such as construction sites and roads near residential areas, especially during the summer.

There were many complaints about water quality, specifically mentioning muddy water and a foul smell in Hopyeong Creek. It was discovered that these complaints were made in places where contaminants from construction sites had entered regions that members of the public visit very frequently. Public complaints about water quality management included "Under the Fifth Bridge, Hopyeong-dong, there is a drainage of water flowing into the creek. It smells foul, so it should be checked in person and addressed," and "In Homan Creek, Hopyeong-dong, muddy water is flowing down all day long and it seems that it's being discharged from the construction site behind the middle and high school. Please come to check and address the matter." Based on these complaints, it is clear that pollutants must be investigated upstream of the Hopyeong Creek, and polluting substances must be prevented from entering the creek.

Many of the public complaints about wildlife in Sudong-myeon were observed at the point of contact between mountains and residential areas. Public complaints about wildlife included "In Jidun-ri, Sudong-myeon, a wild boar appeared and caused damage," and "In Oebang-ri, Sudong-myeon, a wild 
boar came down again and dug the crops up all over the place, so please hurry and capture it. We get phone calls about it all the time, but it seems it's never been handled". To address these complaints, the area where wild boars are active must be cordoned off from areas where locals reside.

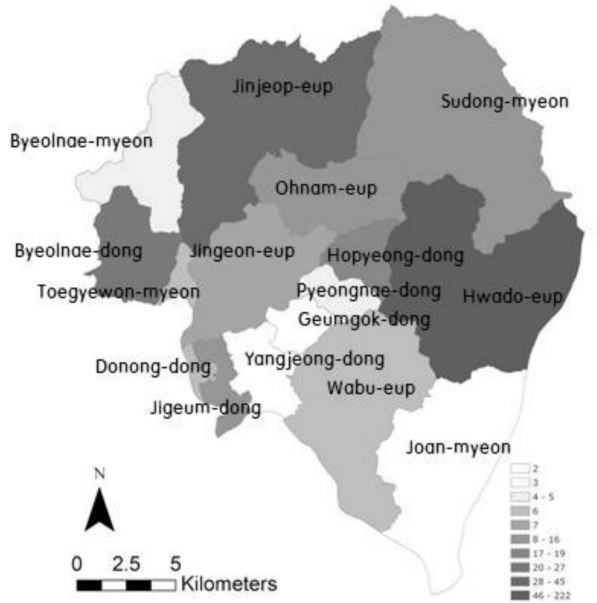

Noise and oscillation [Aug]

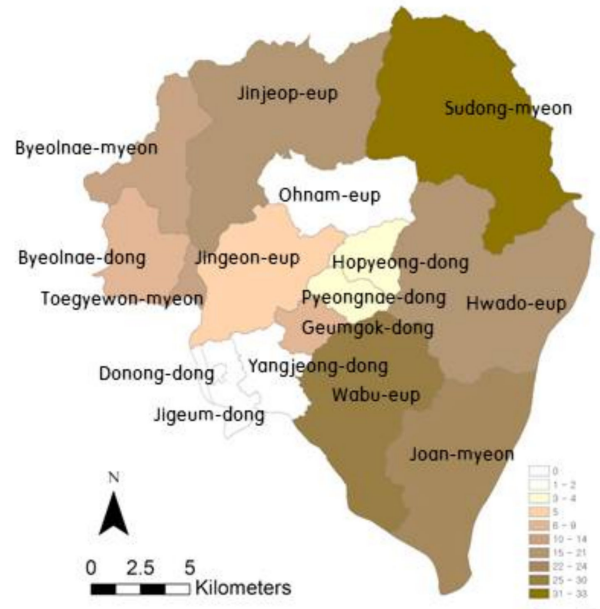

Wild animals and plants [Jul]

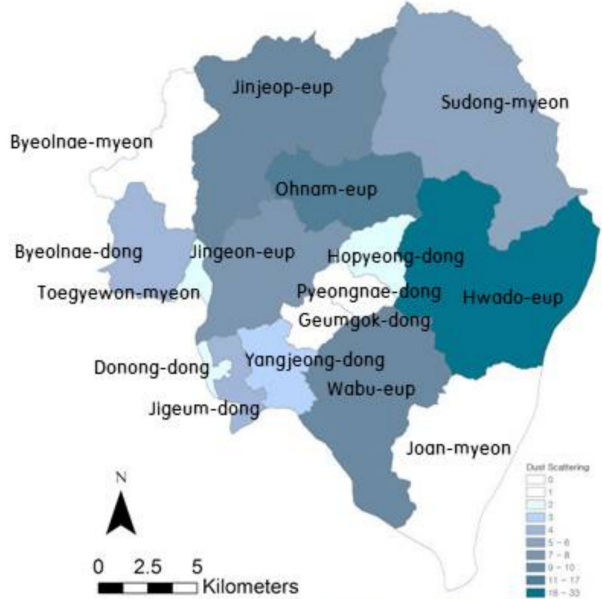

Dust scattering [Nov]

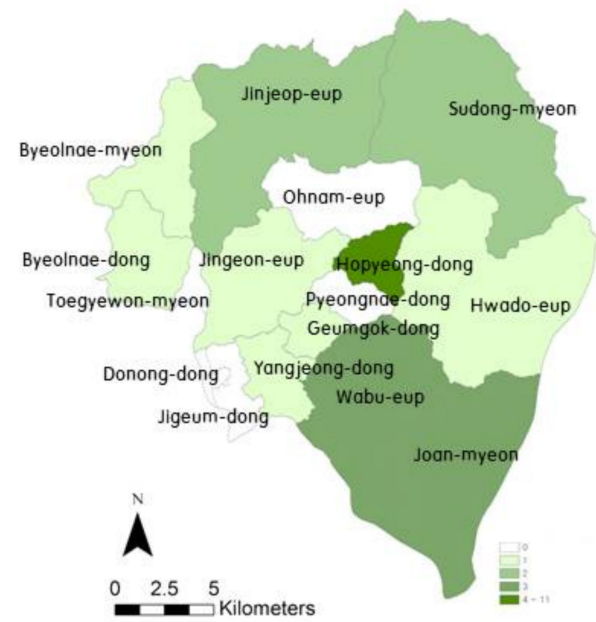

Water Quality management [Aug]

Figure 4. Complaints by municipal areas in the month where the most complaints were received. 


\section{Discussion}

A general analysis of the environmental complaints filed in Namyangju revealed that there were many complaints about the regulation of services regarding noise and oscillation, dust scattering, air quality management, and water quality management. There were also complaints about supporting services for wildlife. Namyangju should urgently introduce plans to improve the regulation of services.

The detailed temporal and spatial analysis of public complaints indicated that most complaints were filed in the summer, but public complaints about dust scattering were reported throughout the year. When mapped, complaints about dust scattering were distributed across the downtown area, while complaints about noise and oscillation and air quality management were concentrated in specific areas. There were many complaints about water quality management in widely-used areas where pollutants had entered the stream. Complaints about wildlife appeared sporadically in areas where mountains abut residential areas. Based on the data, a year-round measure should be implemented in the downtown area to resolve the issue of dust scattering. A measure that addresses noise and oscillation and air quality management should be implemented during the summer in specific affected areas. To resolve water quality management issues, measures should be taken to prevent pollutants from entering the water. To address issues regarding wildlife, policies to separate wild boar habitats from human residential areas are necessary.

An examination of the contents of the public complaints further revealed that people complained about dust scattering, noise and oscillation, air quality management, and water quality management near apartment building construction sites. Apartment building construction companies should, therefore, be encouraged by local governments to actively provide funds through a payment system for ecosystem services [19-24] in order to reduce the risks to ecosystem benefits.

Most environmental complaints originated from the meeting points of hazards to ecosystem services and residential areas. This shows that spatial planning approaches are needed to reduce the inconvenience caused by construction, pollution, and wild animals [57-59]. Construction management for noise and dust reduction and differentiation of roads used by construction and resident vehicles are also recommended. Further, pollution management in residential areas and creating separate spaces for wild animals and residents are required. This study suggests that finding local issue-based planning policies will aid the promotion of ecosystem services [54].

\section{Conclusions}

This study conducted an analysis of public environmental complaints to investigate the factors that prevent ecosystem services from reaching people. Public complaints about ecosystem services can provide important information for environmental planning. This study conducted content, temporal, and spatial analyses of environmental complaints using a geographical information system to examine environmental policy alternatives and decrease the hazards of ecosystem services [16,28,29,31,60-65] based on local issues [54]. The analysis of public complaints can help reduce various negative environmental factors, which can enable citizens to resolve their problems related to ecosystem services. We, therefore, suggest that public complaints regarding ecosystem services be analyzed to develop solutions and establish plans for maximizing local ecosystem services.

Author Contributions: J.-h.L. designed and structured the article. H.C. provided expertise in discussing the design proposal and conclusion. All authors have read and agreed to the published version of the manuscript.

Funding: This work was funded by the National Institute of Ecology in Korea (NIE-Strategy research-201708-1).

Conflicts of Interest: The authors declare no conflict of interest.

\section{References}

1. Boyd, J.; Banzhaf, S. What are ecosystem services? The need for standardized environmental accounting units. Ecol. Econ. 2007, 63, 616-626. [CrossRef] 
2. Fisher, B.; Turner, R.K. Ecosystem services: Classification for valuation. Biol. Conserv. 2008, 141, 1167-1169. [CrossRef]

3. Fisher, B.; Turner, R.K.; Morling, P. Defining and classifying ecosystem services for decision making. Ecol. Econ. 2009, 68, 643-653. [CrossRef]

4. Millennium Ecosystem Assessment (MEA). Ecosystems and Human Well-Being: Synthesis; Island Press: Washington, DC, USA, 2005.

5. Nahlik, A.M.; Kentula, M.E.; Fennessy, M.S.; Landers, D.H. Where is the consensus? A proposed foundation for moving ecosystem service concepts into practice. Ecol. Econ. 2012, 77, 27-35. [CrossRef]

6. Seppelt, R.; Dormann, C.F.; Eppink, F.V.; Lautenbach, S.; Schmidt, S. A quantitative review of ecosystem service studies: Approaches, shortcomings and the road ahead. J. Appl. Ecol. 2011, 48, 630-636. [CrossRef]

7. Barral, M.P.; Oscar, M.N. Land-use planning based on ecosystem service assessment: A case study in the Southeast Pampas of Argentina. Agric. Ecosyst. Environ. 2012, 154, 34-43. [CrossRef]

8. Hauck, J.; Görg, C.; Varjopuro, R.; Ratamäki, O.; Maes, J.; Wittmer, H.; Jax, K. “Maps have an air of authority": Potential benefits and challenges of ecosystem service maps at different levels of decision making. Ecosyst. Serv. 2013, 4, 25-32. [CrossRef]

9. McKenzie, E.; Posner, S.; Tillmann, P.; Bernhardt, J.R.; Howard, K.; Rosenthal, A. Understanding the use of ecosystem service knowledge in decision making: Lessons from international experiences of spatial planning. Environ. Plann. C Gov. Policy 2014, 32, 320-340. [CrossRef]

10. Dasgupta, S.; Wheeler, D. Citizen Complaints as Environmental Indicators: Evidence from China; The World Bank: Washington, DC, USA, 1997; Volume 1704.

11. Balvanera, P.; Pfisterer, A.B.; Buchmann, N.; He, J.S.; Nakashizuka, T.; Raffaelli, D.; Schmid, B. Quantifying the evidence for biodiversity effects on ecosystem functioning and services. Ecol. Lett. 2006, 9, 1146-1156. [CrossRef]

12. De Bello, F.; Lavorel, S.; Díaz, S.; Harrington, R.; Cornelissen, J.H.; Bardgett, R.D.; Berg, M.P.; Cipriotti, P.; Feld, C.K.; Hering, D.; et al. Towards an assessment of multiple ecosystem processes and services via functional traits. Biodivers. Conserv. 2010, 19, 2873-2893. [CrossRef]

13. De Groot, R.S.; Wilson, M.A.; Boumans, R.M. A typology for the classification, description and valuation of ecosystem functions, goods and services. Ecol. Econ. 2012, 41, 393-408. [CrossRef]

14. Delgado-Baquerizo, M.; Maestre, F.T.; Reich, P.B.; Jeffries, T.C.; Gaitan, J.J.; Encinar, D.; Berdugo, M.; Campbell, C.D.; Singh, B.K. Microbial diversity drives multifunctionality in terrestrial ecosystems. Nat. Commun. 2016, 7, 10541. [CrossRef] [PubMed]

15. Bennett, E.M.; Peterson, G.D.; Gordon, L.J. Understanding relationships among multiple ecosystem services. Ecol. Lett. 2009, 12, 1394-1404. [CrossRef] [PubMed]

16. Danielsen, F.; Burgess, N.D.; Balmford, A. Monitoring matters: Examining the potential of locally-based approaches. Biodivers. Conserv. 2005, 14, 2507-2542. [CrossRef]

17. Wilson, M.A.; Howarth, R.B. Discourse-based valuation of ecosystem services: Establishing fair outcomes through group deliberation. Ecol. Econ. 2002, 41, 431-443. [CrossRef]

18. Zhang, W.; Ricketts, T.H.; Kremen, C.; Carney, K.; Swinton, S.M. Ecosystem services and dis-services to agriculture. Ecol. Econ. 2007, 64, 253-260. [CrossRef]

19. Chen, X.; Lupi, F.; He, G.; Ouyang, Z.; Liu, J. Factors affecting land reconversion plans following a payment for ecosystem service program. Biol. Conserv. 2009, 142, 1740-1747. [CrossRef]

20. Engel, S.; Pagiola, S.; Wunder, S. Designing payments for environmental services in theory and practice: An overview of the issues. Ecol. Econ. 2008, 65, 663-674. [CrossRef]

21. Farber, S.C.; Costanza, R.; Wilson, M.A. Economic and ecological concepts for valuing ecosystem services. Ecol. Econ. 2002, 41, 375-392. [CrossRef]

22. Gross-Camp, N.D.; Martin, A.; McGuire, S.; Kebede, B.; Munyarukaza, J. Payments for ecosystem services in an African protected area: Exploring issues of legitimacy, fairness, equity and effectiveness. Oryx 2012, 46, 24-33. [CrossRef]

23. Sommerville, M.; Jones, J.P.; Rahajaharison, M.; Milner-Gulland, E. The role of fairness and benefit distribution in community-based payment for environmental services interventions: A case study from Menabe, Madagascar. Ecol. Econ. 2010, 69, 1262-1271. [CrossRef]

24. Redford, K.H.; Adams, W.M. Payment for ecosystem services and the challenge of saving nature. Conserv. Biol. 2009, 23, 785-787. [PubMed] 
25. Dong, Y.; Ishikawa, M.; Liu, X.; Hamori, S. The determinants of citizen complaints on environmental pollution: An empirical study from China. J. Clean Prod. 2011, 19, 1306-1314. [CrossRef]

26. Zhang, X.; Geng, G.; Sun, P. Determinants and implications of citizens' environmental complaint in China: Integrating theory of planned behavior and norm activation model. J. Clean Prod. 2017, 166, 148-156. [CrossRef]

27. Chung, J.-W.; Lee, M.-E.; Lee, H.-D. Characteristics of environmental pollution related with public complaints in an industrial shipbuilding complex, Korea. Environ. Monit. Assess. 2011, 177, 73-84. [CrossRef] [PubMed]

28. Coussement, K.; Van den Poel, D. Improving customer complaint management by automatic email classification using linguistic style features as predictors. Decis. Support. Syst. 2008, 44, 870-882. [CrossRef]

29. Fornell, C.; Wernerfelt, B. Defensive marketing strategy by customer complaint management: A theoretical analysis. J. Mark. Res. 1987, 24, 337-346. [CrossRef]

30. Oly Ndubisi, N.; Yin Ling, T. Complaint behaviour of Malaysian consumers. Manag. Res. News 2006, 29, 65-76. [CrossRef]

31. Tax, S.S.; Brown, S.W.; Chandrashekaran, M. Customer evaluations of service complaint experiences: Implications for relationship marketing. J. Mark. 1998, 62, 60-76. [CrossRef]

32. Cho, Y.; Im, I.; Hiltz, R.; Fjermestad, J. An Analysis of Online Customer Complaints: Implications for Web Complaint Management. In Proceedings of the 35th Annual Hawaii International Conference on System Science, Big Island, HI, USA, 10 January 2002.

33. Park, Y.; Lee, S. How to design and utilize online customer center to support new product concept generation. Expert Syst. Appl. 2011, 38, 10638-10647. [CrossRef]

34. $\mathrm{Wu}, \mathrm{L}$. The antecedents of customer satisfaction and its link to complaint intentions in online shopping: An integration of justice, technology, and trust. Int. J. Inform. Manag. 2013, 33, 166-176. [CrossRef]

35. Lee, C.C.; Hu, C. Analyzing hotel customers' E-complaints from an internet complaint forum. J. Travel Tour. Market. 2005, 17, 167-181. [CrossRef]

36. Ngai, E.W.; Heung, V.C.; Wong, Y.; Chan, F.K. Consumer complaint behaviour of Asians and non-Asians about hotel services: An empirical analysis. Eur. J. Mark. 2007, 41, 1375-1391. [CrossRef]

37. Ngo, A.; Revesz, P. Efficient Traffic Crash and Snow Complaint GIS system. In Proceedings of the 12th Annual International Digital Government Research Conference: Digital Government Innovation in Challenging Times, College Park, MD, USA, 12-15 June 2011.

38. Yavas, U.; Karatepe, O.M.; Babakus, E.; Avci, T. Customer complaints and organizational responses: A study of hotel guests in Northern Cyprus. J. Hospit. Leis. Market. 2004, 11, 31-46. [CrossRef]

39. Aurit, M.D.; Peterson, R.O.; Blanford, J.I. A GIS analysis of the relationship between sinkholes, dry-well complaints and groundwater pumping for frost-freeze protection of winter strawberry production in Florida. PLOS ONE 2013, 8, e53832. [CrossRef]

40. Burkhard, B.; Kroll, F.; Nedkov, S.; Müller, F. Mapping ecosystem service supply, demand and budgets. Ecol. Indic. 2012, 21, 17-29. [CrossRef]

41. Forrester, D.I. The spatial and temporal dynamics of species interactions in mixed-species forests: From pattern to process. Forest Ecol. Manag. 2014, 312, 282-292. [CrossRef]

42. Lautenbach, S.; Seppelt, R.; Liebscher, J.; Dormann, C.F. Spatial and temporal trends of global pollination benefit. PLoS ONE 2012, 7, e35954. [CrossRef]

43. Schwartz, C.C.; Haroldson, M.A.; White, G.C.; Harris, R.B.; Cherry, S.; Keating, K.A.; Moody, D.; Servheen, C. Temporal, spatial, and environmental influences on the demographics of grizzly bears in the Greater Yellowstone Ecosystem. Wildl. Monogr. 2006, 1-68. [CrossRef]

44. Goldstein, J.H.; Caldarone, G.; Duarte, T.K.; Ennaanay, D.; Hannahs, N.; Mendoza, G.; Polasky, S.; Wolny, S.; Daily, G.C. Integrating ecosystem-service tradeoffs into land-use decisions. Proc. Natl. Acad. Sci. USA 2012, 109, 7565-7570. [CrossRef]

45. Tscharntke, T.; Klein, A.M.; Kruess, A.; Steffan-Dewenter, I.; Thies, C. Landscape perspectives on agricultural intensification and biodiversity-ecosystem service management. Ecol. Lett. 2005, 8, 857-874. [CrossRef]

46. Dang, K.B.; Windhorst, W.; Burkhard, B.; Müller, F. A Bayesian Belief Network-Based approach to link ecosystem functions with rice provisioning ecosystem services. Ecol. Indic. 2019, 100, 30-44. [CrossRef]

47. Guo, Z.; Xiao, X.; Li, D. An assessment of ecosystem services: Water flow regulation and hydroelectric power production. Ecol. Appl. 2000, 10, 925-936. [CrossRef] 
48. Ko, H.; Son, Y. Perceptions of cultural ecosystem services in urban green spaces: A case study in Gwacheon, Republic of Korea. Ecol. Indic. 2018, 91, 299-306. [CrossRef]

49. Pan, H.; Page, J.; Zhang, L.; Cong, C.; Ferreira, C.; Jonsson, E.; Nasstrom, H.; Destouni, G.; Deal, B.; Kalantari, Z. Understanding interactions between urban development policies and GHG emissions: A case study in Stockholm Region. Ambio 2019, 1-15. [CrossRef] [PubMed]

50. Pan, H.; Zhang, L.; Cong, C.; Deal, B.; Wang, Y. A dynamic and spatially explicit modeling approach to identify the ecosystem service implications of complex urban systems interactions. Ecol. Indic. 2019, 102, 426-436. [CrossRef]

51. Goldenberg, R.; Kalantari, Z.; Cvetkovic, V.; Mörtberg, U.; Deal, B.; Destouni, G. Distinction, quantification and mapping of potential and realized supply-demand of flow-dependent ecosystem services. Sci. Total Environ. 2017, 593, 599-609. [CrossRef]

52. Liquete, C.; Piroddi, C.; Drakou, E.G.; Gurney, L.; Katsanevakis, S.; Charef, A.; Egoh, B. Current status and future prospects for the assessment of marine and coastal ecosystem services: A systematic review. PLoS ONE 2013, 8, 8. [CrossRef]

53. Schulp, C.J.E.; Lautenbach, S.; Verburg, P.H. Quantifying and mapping ecosystem services: Demand and supply of pollination in the European Union. Ecol. Indic. 2014, 36, 131-141. [CrossRef]

54. Riechers, M.; Barkmann, J.; Tscharntke, T. Perceptions of cultural ecosystem services from urban green. Ecosyst. Serv. 2016, 17, 33-39. [CrossRef]

55. Choi, H. Geospatial Data Approach for Demand-Oriented Policies of Land Administration. Land 2020, 9, 31. [CrossRef]

56. Min, K.; Jun, B.; Lee, J.; Kim, H.; Furuya, K. Analysis of Environmental Issues with an Application of Civil Complaints: The Case of Shiheung City, Republic of Korea. Int. J. Environ. Res. Public Health 2019, 16, 1018. [CrossRef] [PubMed]

57. Carvalho, D.S.; Fidélis, T. The perception of environmental quality in Aveiro, Portugal: A study of complaints on environmental issues submitted to the City Council. Local Environ. 2009, 14, 939-961. [CrossRef]

58. Hopcraft, I.J. Shade and daylight loss to dwellings-The complaint zone. Arboric. J. 2012, 34, $124-133$. [CrossRef]

59. Meligrana, J.; Li, Z.; Zhang, Z. Resolving land use disputes in China: An analysis of a method of dealing with citizen complaints. Environ. Urban. ASIA 2011, 2, 251-264. [CrossRef]

60. Yu, K.-M.; Shin, J.-B.; Naruse, T. Loess-paleosol stratigraphy of Dukso area, Namyangju City, Korea (South). Quat. Int. 2008, 176, 96-103. [CrossRef]

61. Carvalho, D.S.; Fidélis, T. Environmental complaints in Aveiro, Portugal: Actors, concerns, territorial pattern, and resolutions. Soc. Nat. 2009, 21, 51-70. [CrossRef]

62. Jean Harrison-Walker, L. E-complaining: A content analysis of an Internet complaint forum. J. Serv. Mark. 2001, 15, 397-412. [CrossRef]

63. Duncan, D.T.; Tamura, K.; Regan, S.D.; Elbel, B.; Meline, J.; Al-Ajlouni, Y.A.; Chaix, B. Quantifying spatial misclassification in exposure to noise complaints among low-income housing residents across New York City neighborhoods: A Global Positioning System (GPS) study. Ann. Epidemiol. 2017, 27, 67-75. [CrossRef] [PubMed]

64. Hinrichs, U.; Alex, B.; Clifford, J.; Watson, A.; Quigley, A.; Klein, E.; Coates, C.M. Trading consequences: A case study of combining text mining and visualization to facilitate document exploration. Digit. Scholarsh. Humanit. 2015, 30 (Suppl. 1), i50-i75. [CrossRef]

65. Robertson, M.M. The neoliberalization of ecosystem services: Wetland mitigation banking and problems in environmental governance. Geoforum 2004, 35, 361-373. [CrossRef]

(C) 2020 by the authors. Licensee MDPI, Basel, Switzerland. This article is an open access article distributed under the terms and conditions of the Creative Commons Attribution (CC BY) license (http://creativecommons.org/licenses/by/4.0/). 